Dinamika Sosial Budaya, Vol 19, No. 2, Desember 2017, pp 199-208

p-ISSN: 1410-9859\& e-ISSN: 2580-8524

http://journals.usm.ac.id/index.php/jdsb

\title{
KEBIJAKAN PERLUASAN ALAT BUKTI HUKUM ACARA \\ PIDANADALAM UPAYA MEWUJUDKAN KEPASTIAN \\ HUKUM BERKEADILAN
}

\author{
Ani Triwati, \\ Fakultas Hukum, Universitas Semarang, \\ A. Heru Nuswanto, \\ Fakultas Hukum, Universitas Semarang, \\ Endah Pujiastuti \\ Fakultas Hukum, Universitas Semarang,
}

\begin{abstract}
Abstrak
Salah satu pembaharuan instrumen hukum dalam hukum acara pidana adalah adanya perluasan alat bukti yaitu informasi elektronik dan/ atau dokumen elektronik dan/atau hasil cetakannya. Pengaturan alat bukti dalam hukum acara pidana di Indonesia sesuai dengan Pasal 184 KUHAP, Pasal 5 ayat (1) dan (2) serta Pasal 44 huruf Undang-Undang Informasi dan Transaksi Elektronik, yaitu meliputi keterangan saksi, keterangan ahli, surat, petunjuk, keterangan terdakwa, informasi elektronik dan/atau dokumen elektronik dan/atau hasil cetaknya. Adanya putusan Mahkamah Konstitusi Nomor 20/ PUU-XIV/2016 bahwa untuk informasi elektronik dan/ atau dokumen elektronik sebagai alat bukti dilakukan dalam rangka penegakan hukum atas permintaan kepolisian, kejaksaan dan/atau institusi penegak hukum lainnya yang ditetapkan berdasarkan undang-undang. Informasi elektronik dan/ atau dokumen elektronik sebagai alat bukti harus diperoleh sesuai dengan ketentuanPasal 31 ayat (3) Undang-Undang Informasi dan Transaksi Elektronik, hal ini berkaitan dengan nilai kepastian hukum dan nilai keadilan bagi pihak yang berperkara.
\end{abstract}

Kata kunci : Perluasan, alat bukti, acara pidana, kepastian hukum, berkeadilan.

\begin{abstract}
One of the renewal of legal instruments in criminal procedural law is the expansion of evidence ie electronic information and / or electronic document and / or its printed outcome. Arrangement of evidence in criminal procedural law in Indonesia pursuant to Article 184 KUHAP, Article 5 paragraph (1) and (2) and Article 44 letter of Information and Electronic Transaction Act, covering witness statements, expert information, letters, instructions, defendants, electronic information and / or electronic documents and / or prints. The decision of the Constitutional Court Number 20 / PUU-XIV / 2016 that for electronic information and / or electronic document as evidence is done in the framework of law enforcement at the request of the police, prosecutor and / or other law enforcement institutions determined by law. Electronic information and / or electronic documents as evidence must be obtained in accordance with the provisions of Article 31 paragraph (3) of the Information and Electronic Transactions Act, this relates to the value of legal certainty and the value of justice for the litigant.
\end{abstract}

Keywords: Expansion, evidence, criminal procedural law, legal certainty justice. 


\section{A. Latar Belakang}

Pembuktian merupakan bagian dari pemeriksaan perkara pidana yang mempunyai peranan sangat penting, hal ini berkaitan dengan keyakinan hakim dalam menjatuhkan putusan yang didasarkan pada minimal dua alat bukti. Hukum acara pidana mengatur mengenai minimal dua alat bukti yang mendasari keyakinan hakim dalam menjatuhkan putusan, yang diatur dalam Pasal 183 Undang-Undang Nomor 8 Tahun 1981 tentang Hukum Acara Pidana (untuk selanjutnya disebut KUHAP). ${ }^{1}$ Selanjutnya mengenai alat bukti dalam hukum acara pidana, sebagaimana Pasal 184 ayat (1) KUHAP bahwa alat bukti yang sah adalah keterangan saksi, keterangan ahli, surat, petunjuk dan keterangan terdakwa.Perkembangan tindak pidana yang beriringan dengan perkembangan ilmu pengetahuan dan teknologi sudah seharusnya diikuti dengan pembaharuan instrumen hokum.

Salah satu pembaharuan hukum dalam perkara pidana adalah adanya perluasan alat bukti dalam hukum acara pidana. Informasi elektronik dan/ atau dokumen elektronik dan/atau hasil cetakannya merupakan perluasan alat bukti dalam hukum acara pidana, sebagai kebijakan negara dalam pembaharuan hukum khususnya hukum pidana formil.Adanya putusan Mahkamah Konstitusi Nomor 20/ PUU-XIV/2016, dalam perkara pengujian Pasal 5 ayat (1) dan ayat (2) serta Pasal 44 huruf b Undang-Undang ITE dan Pasal 26A Undang-Undang Pemberantasan Tindak Pidana Korupsi, memberikan perhatian tersendiri mengenai kewenangan proses penyadapan. Putusan Mahkamah

\footnotetext{
1 Pasal 183 KUHAP: "Hakim tidak boleh menjatuhkan pidan kepada seorang kecuali apabila dengan sekurang-kurangnya dua alat bukti yang sah ia memperoleh keyakinan bahwa suatu tindak pidana benar-benar terjadi dan bahwa terdakwalah yang bersalah melakukannya."
}

Konstitusi Nomor 20/ PUU-XIV/2016, menyatakan bahwa frasa informasi elektronik dan/ atau dokumen elektronik dalam Pasal 5 ayat (1) dan ayat (2) serta Pasal 44 huruf b Undang-Undang ITE bertentangan dengan Undang-Undang Dasar Negara Republik Indonesia Tahun 1945 dan tidak mempunyai kekuatan hukum mengikat, sepanjang tidak dimaknai khususnya frasa Informasi elektronik dan/ atau dokumen elektronik sebagai alat bukti dilakukan dalam rangka penegakan hukum atas permintaan kepolisian, kejaksaan dan/atau institusi penegak hukum lainnya yang ditetapkan berdasarkan undang-undang sebagaimana ditentukan dalam Pasal 31 ayat (3) Undang-Undang ITE.

$$
\text { Selanjutnya dalam Putusan }
$$

Mahkamah Konstitusi Nomor 20/ PUUXIV/2016, juga menyatakan bahwa frasa informasi elektronik dan/ atau dokumen elektronik dalam Pasal 26A UndangUndang Nomor 20 Tahun 2001 tentang Perubahan Undang-Undang Nomor 31 Tahun 1999 tentang Pemberantasan Tindak Pidana Korupsi bertentangan dengan Undang-Undang Dasar Negara Republik Indonesia Tahun 1945 dan tidak mempunyai kekuatan hukum mengikat, sepanjang tidak dimaknai khususnya frasa Informasi elektronik dan/ atau dokumen elektronik sebagai alat bukti dilakukan dalam rangka penegakan hukum atas permintaan kepolisian, kejaksaan dan/atau institusi penegak hukum lainnya yang ditetapkan berdasarkan undang-undang sebagaimana ditentukan dalam Pasal 31 ayat (3) Undang-Undang ITE. Dengan adanya putusan Mahkamah Konstitusi tersebut, informasi elektronik dan/ atau dokumen elektronik sebagai alat bukti dilakukan dalam rangka penegakan hukum atas permintaan kepolisian, kejaksaan dan/atau institusi penegak hukum lainnya yang ditetapkan berdasarkan undangundang. Hal ini berkaitan dengan nilai kepastian hukum dan nilai keadilan bagi pihak yang berperkara. 
Berdasarkan uraian latar belakang tersebut, perlu dilakukan penelitian mengenai perluasan alat bukti hukum acara pidana dalam mewujudkan kepastian hukum yang berkeadilan.

\section{B. Perumusan Masalah}

1. Bagaimana pengaturan mengenai alat bukti dalam hukum acara pidana?

2. Bagaimana perluasan alat bukti informasi elektronik dan/ atau dokumen elektronik dapat mewujudkan kepastian hukum yang berkeadilan?

\section{Tujuan Penelitian}

Penelitian ini lebih bertujuan untuk kepentingan akademis dan untuk kepentingan praktek di Pengadilan, sehingga penelitian iniuntuk mengetahui:

1. Pengaturan mengenai alat bukti dalam hukum acara pidana.

2. Perluasan alat bukti informasi elektronik dan/ atau dokumen elektronik dapat mewujudkan kepastian hukum yang berkeadilan.

\section{Manfaat Penelitian}

1. Memberikan pemahaman kepada mahasiswa, akademisi, masyarakat, aparat penegak hukum dan institusi terkait mengenai pengaturan alat bukti dalam hukum acara pidana di Indonesia.

2. Memberikan pemahaman kepada mahasiswa, akademisi, masyarakat, aparat penegak hukum dan institusi terkait bahwa perluasan alat bukti informasi elektronik dan/ atau dokumen elektronik dapat mewujudkan kepastian hukum yang berkeadilan.

\section{E. Tinjauan Pustaka}

1. Kebijakan Hukum Pidana Pembaharuan hukum pidana harus ditempuh dengan pendekatan yang berorientasi pada kebijakan, karena pada hakikatnya ia hanya merupakan bagian dari langkah kebijakan atau "policy" (yaitu bagian dari politik hukum/ penegakan hukum, politik hukum pidana, politik kriminal, dan politik sosial). Di dalam setiap kebijakan (policy) terkandung pula nilai. Oleh karena itu, pembaharuan hukum pidana harus pula berorientasi pada pendekatan-nilai. $^{2}$

Politik kriminal (criminal policy) adalah usaha rasional untuk menanggulangi kejahatan. Politik kriminal ini merupakan bagian dari politik penegakan hukum dalam arti luas (law enforcement policy). ${ }^{3}$ Politik kriminal dan politik penegakan hukum merupakan bagian dari politik sosial. Politik sosial adalah usaha negara dalam upaya meningkatkan kesejahteraan masyarakatnya. Pembaharuan hukum pidana dalam hal ini hukum pidana formil adalah bagian dari usaha negara untuk menanggulangi kejahatan dalam upaya meningkatkan kesejahteraan masyarakatnya.

Kebijakan hukum pidana (penal policy), menurut Marc Ancel adalah suatu ilmu sekaligus seni yang pada akhirnya mempunyai tujuan praktis yang memungkinkan peraturan hukum positif dirumuskan secara lebih baik dan untuk memberi pedoman tidak hanya kepada pembuat undang-undang dan juga kepada penyelenggara negara atau pelaksana putusan pengadilan. ${ }^{4}$

\footnotetext{
${ }^{2}$ Barda Nawawi Arief, Bunga Rampai Kebijakan Hukum Pidana: Perkembangan Penyusunan Konsep KUHP Baru, (Jakarta: Kencana Prenadamedia Group, 2014), halaman 29.

${ }^{3}$ Muladi dan Barda Nawawi Arief, Bunga Rampai Hukum Pidana (Bandung: PT. Alumni, 2010), halaman 1.
}

${ }^{4}$ Nawawi Arief, op. cit., halaman 23. 
Dengan demikian pembaharuan dalam hukum acara pidana dengan tujuan untuk dirumuskan lebih baik sesuai dengan perkembangan ilmu dan teknologi khususnya mengenai alat bukti, yang selanjutnya dapat digunakan sebagai pedoman dalam proses peradilan pidana bagi aparat penegak hukum dan institusi terkait.

2. Alat Bukti dalam Kitab UndangUndang Hukum Acara Pidana Pembuktian adalah ketentuanketentuan yang berisi penggarisan dan pedoman tentang cara-cara yang dibenarkan undang-undang membuktikan kesalahan yang didakwakan. ${ }^{5}$ Alat bukti dalam hukum acara pidana, terdapat dalam Pasal 184 KUHAP bahwa alat bukti yang sah ialah keterangan saksi, keterangan ahli, surat, petunjuk dan keterangan terdakwa (ayat (1)). Selanjutnya dalam ayat (2) disebutkan bahwa hal yang secara umum sudah diketahui tidak perlu dibuktikan.

3. Alat Bukti Informasi elektronik dan/ atau dokumen elektronik

Pengertian atau definisi informasi elektronik dalam Undang-Undang ITE Pasal 1 angka 1 :

Informasi Elektronik adalah satu atau sekumpulan data elektronik, termasuk tetapi tidakterbatas pada tulisan, suara, gambar, peta, rancangan, foto, electronic data interchange $(E D I)$, surat elektronik (electronic mail), telegram, teleks, telecopy atau sejenisnya, huruf,tanda, angka, Kode Akses, simbol, atau

\footnotetext{
${ }^{5}$ M. Yahya Harahap, Pembahasan Permasalahan dan Penerapan KUHAP Pemeriksaan Sidang Pengadilan, Banding, Kasasi dan Peninjauan Kembali (Jakarta: Sinar Grafika, 2009), halaman 273.
}

perforasi yang telah diolah yang memiliki arti ataudapat dipahami oleh orang yang mampu memahaminya.

Selanjutnya pengertian dokumen elektronik dalam Undang-Undang ITE Pasal 1 angka 4:

Dokumen Elektronik adalah setiap Informasi Elektronik yang dibuat, diteruskan, dikirimkan,diterima, atau disimpan dalam bentuk analog, digital, elektromagnetik, optikal, atausejenisnya, yang dapat dilihat, ditampilkan, dan/atau didengar melalui Komputer atauSistem Elektronik, termasuk tetapi tidak terbatas pada tulisan, suara, gambar, peta,rancangan, foto atau sejenisnya, huruf, tanda, angka, Kode Akses, simbol atau perforasiyang memiliki makna atau arti atau dapat dipahami oleh orang yang mampumemahaminya.

Informasi elektronik dan atau dokumen elektronik dan/atau hasil cetakannya sebagai perluasan alat bukti, ditentukan dalam Pasal 5 Undang-Undang ITE:

(1) Informasi Elektronik dan/atau Dokumen Elektronik dan/atau hasil cetaknya merupakanalat bukti hukum yang sah.

(2) Informasi Elektronik dan/atau Dokumen

Elektronik dan/atau hasil cetaknya sebagaimana dimaksud pada ayat (1) merupakan perluasan dari alat bukti yang sah sesuai dengan Hukum Acara yang berlaku di Indonesia.

(3) Informasi Elektronik dan/atau Dokumen Elektronik dinyatakan sah apabila menggunakan Sistem Elektronik sesuai 


$\begin{array}{lr}\text { dengan ketentuan yang } \\ \text { diatur dalam } & \text { Undang- } \\ \text { Undang ini. } & \\ \text { Ketentuan } & \text { mengenai } \\ \text { Informasi } & \text { Elektronik } \\ \text { dan/atau ran } & \text { Dokumen } \\ \text { Elektronik sebagaimana } & \text { dimaksud pada ayat (1) } \\ \text { tidak berlaku untuk: }\end{array}$

a. surat yang menurut Undang-Undang harus dibuat dalam bentuk tertulis; dan

b. surat beserta dokumennya yang menurut UndangUndang harus dibuat dalam bentuk akta notaril atau akta yang dibuat oleh pejabat pembuat akta.

44 Undang-Undang Pasal menentukan bahwa alat bukti penyidikan, penuntutan dan pemeriksaan di sidang pengadilan menurut ketentuanUndang-Undang ini adalah sebagai berikut:

a. alat bukti sebagaimana dimaksud dalam ketentuan Perundang-undangan; dan

b. alat bukti lain berupa informasi elektronik dan/atau dokumen elektronik

sebagaimanadimaksud dalam Pasal 1 angka 1 dan angka 4 serta Pasal 5 ayat (1), ayat (2), dan ayat(3).

Dengan demikian, alat bukti dalam hukum acara (hukum acara pidana) yang terdapat dalam KUHAP yaitu keterangan saksi, keterangan ahli, surat, petunjuk, dan keterangan terdakwa, diperluas atau ditambah dengan informasi elektronik dan atau dokumen elektronik dan/atau hasil cetakannya.

\section{F. Metode Penelitian}

Jenis penelitian yang digunakan adalah yuridis normatif. Penelitian hukum normatif adalah penelitian hukum yang meletakkan hukum sebagai sebuah bangunan sistem norma. Sistem norma yang dimaksud adalah mengenai asas-asas, norma, kaidah dari peraturan perundang-undangan, putusan pengadilan, perjanjian serta doktrin (ajaran). ${ }^{6}$ Penelitian ini dilakukan secara deskriptif analitis yang merupakan cara pemecahan masalah penelitian yang dilakukan dengan cara menggambarkan atau mendeskripsikan obyek yang diteliti yaitu peraturan-peraturan yang berkaitan dengan perluasan alat bukti dalam hukum acara pidanayaitu informasi elektronik dan atau dokumen elektronik, kemudian dilakukan analisis terhadap obyek dan data telah yang diperoleh tersebut.

Sumber data utama yang digunakan adalah data sekunder dengan menggunakan teknik pengumpulan data melalui studi kepustakaan yaitu memilih dan mengelompokkan aturanaturan atau ketentuan-ketentuan hukum mengenai perluasan alat bukti dalam hukum acara pidanayaitu informasi elektronik dan atau dokumen elektronik. Metode analisis data yang akan dilakukan adalah secara kualitatif normatif, yaitu dengan cara melakukan langkah-langkah kategorisasi, penafsiran, korelasi dan perbandingan terhadap bahan-bahan hukum dan peraturan hukum mengenai mengenai perluasan alat bukti dalam hukum acara pidanayaitu informasi elektronik dan atau dokumen elektronik.

\section{G. Hasil dan Pembahasan}

1. Pengaturan mengenai alat bukti dalam hukum acara pidana.

\footnotetext{
${ }^{6}$ Mukti Fajar ND dan Yulianto Achma, Dualisme Penelitian Hukum Normatif dan Empiris (Yogyakarta: Pustaka Pelajar,2013), halaman 34.
} 
Dilihat dari aspek/ komponen penegakan hukum (legal substance), sistem peradilan pada hakikatnya merupakan suatu sistem penegakan substansi hukum (di bidang hukum pidana meliputi hukum pidana materiel, hukum pidana formal, dan hukum pelaksanaan pidana). ${ }^{7}$ Hukum pidana formal mengatur bagaimana negara dengan perantaraan alat-alat perlengkapannya melaksanakan haknya untuk mengenakan pidana. Hukum pidana formal bisa juga disebut Hukum Acara Pidana. ${ }^{8}$

Pasal 183 KUHAP menyebutkan bahwa hakim tidak boleh menjatuhkan pidana kepada seorang kecuali apabila dengan sekurang-kurangnya dua alat bukti yang sah ia memperoleh keyakinan bahwa suatu tindak pidana benarbenar terjadi dan bahwa terdakwalah yang bersalah melakukannya. Ketentuan Pasal 183 secara eksplisit mengatur mengenai minimal dua alat bukti yang digunakan oleh hakim untuk menjatuhkan putusan disertai dengan keyakinannya. Selanjutnya Pasal 184 KUHAP menentukan alat bukti yang sah dalam hukum acara pidana. Pasal 184 KUHAP menyebutkan dalam ayat (1) bahwa alat bukti yang sah ialah: a. keterangan saksi; b.keterangan ahli; c.surat; d.petunjuk; e.keterangan terdakwa. Selanjutnya dalam ayat (2) bahwa hal yang secara umum sudah diketahui tidak perlu dibuktikan.

Setelah adanya UndangUndang No. 11 Tahun 2008 tentang Informasi dan Transaksi Elektronik sebagaimana diubah

\footnotetext{
${ }^{7}$ Ibid., halaman 6.

${ }^{8}$ Sudarto, Hukum Pidana I, (Semarang: Penerbit Yayasan Sudarto, 2009).
}

dengan Undang-Undang No. 19 Tahun 2016 tentang Perubahan Atas Undang-Undang No. 11 Tahun 2008 tentang Informasi dan Transaksi Elektronik (UndangUndang ITE), alat bukti dalam hukum acara pidana bertambah yaitu dengan adanya informasi elektronik dan dokumen elektronik. Pasal 5 ayat (1) dan (2) UndangUndang ITE menyebutkan :

(1)Informasi Elektronik dan/atau Dokumen Elektronik dan/atau hasil cetaknya merupakan alat bukti hukum yang sah.

(2)Informasi Elektronik dan/atau Dokumen Elektronik dan/atau hasil cetaknya sebagaimana dimaksud pada ayat (1) merupakan perluasan dari alat bukti yang sah sesuai dengan Hukum Acara yang berlaku di Indonesia.

(3)Informasi Elektronik dan/atau Dokumen Elektronik dinyatakan sah apabila menggunakan Sistem Elektronik sesuai dengan ketentuan yang diatur dalam Undang-Undang ini.

Berdasarkan ketentuan Pasal 5 ayat (1) dan (2) Undang-Undang ITE tersebut maka informasi elektronik dan/atau dokumen elektronik dan/atau hasil cetaknya merupakan alat bukti hukum yang sah dalam hukum acara di Indonesia. Berkaitan dengan hukum acara pidana, Pasal 44 Undang-Undang ITE menentukan bahwa alat bukti penyidikan, penuntutan dan pemeriksaan di sidang pengadilan menurut ketentuanUndang-Undang ini adalah sebagai berikut:

a. alat bukti sebagaimana dimaksud dalam ketentuan Perundang-undangan; dan

b. alat bukti lain berupa informasi elektronik dan/atau dokumen 
elektronik

sebagaimanadimaksud dalam Pasal 1 angka 1 dan angka 4 serta Pasal 5 ayat (1), ayat (2), dan ayat(3).

Dengan demikian alat bukti dalam hukum acara pidana di Indonesia sesuai dengan Pasal 184 KUHAP, Pasal 5 ayat (1) dan (2) serta Pasal 44 huruf Undang-Undang ITE, yaitu meliputi keterangan saksi, keterangan ahli, surat, petunjuk, keterangan terdakwa, informasi elektronik dan/atau dokumen elektronik dan/atau hasil cetaknya.

2. Perluasan alat bukti informasi elektronik dan/ atau dokumen elektronik dalam mewujudkan kepastian hukum yang berkeadilan.

Adanya perluasan alat bukti dalam hukum acara pidana selain yang terdapat dalam Pasal 184 KUHAP (keterangan saksi, keterangan ahli, surat, petunjuk, keterangan terdakwa), yaitu adanya informasi elektronik dan/atau dokumen elektronik dan/atau hasil cetaknya (Pasal 5 ayat (1) dan (2) serta Pasal 44 huruf Undang-Undang ITE), merupakan salah satu upaya negara untuk melindungi masyarakatnya khususnya bagi tersangka atau terdakwa.Dengan adanya perluasan alat bukti dalam hukum acara pidana maka tujuan hukum acara pidana untuk memperoleh kebenaran materiil (kebenaran yang sesungguhnya) mempunyai sarana yang lebih luas.

Perlindungan hak tersangka berkaitan dengan cara memperoleh alat bukti adanyainformasi elektronik dan/atau dokumen elektronik, telah diatur dalam Pasal 31 Undang-Undang ITE yang menyebutkan:

(1)Setiap Orang dengan sengaja dan tanpa hak atau melawan hukum melakukan intersepsi atau penyadapan atas Informasi Elektronik dan/atau Dokumen Elektronik dalam suatu Komputer dan/atau Sistem Elektronik tertentu milik Orang lain.

(2)Setiap Orang dengan sengaja dan tanpa hak atau melawan hukum melakukan intersepsi atas transmisi Informasi Elektronik dan/atau Dokumen Elektronik yang tidak bersifat publik dari, ke, dan di dalam suatu Komputer dan/atau Sistem Elektronik tertentu milik Orang lain, baik yang tidak menyebabkan perubahan apa pun maupun yang menyebabkan adanya perubahan, penghilangan, dan/atau penghentian Informasi Elektronik dan/atau Dokumen Elektronik yang sedang ditransmisikan.

(3) Kecuali intersepsi sebagaimana dimaksud pada ayat (1) dan ayat (2), intersepsi yang dilakukan dalam rangka penegakan hukum atas permintaan kepolisian, kejaksaan, dan/atau institusi penegak hukum lainnya yang ditetapkan berdasarkan undangundang.

(4) Ketentuan lebih lanjut mengenai tata cara intersepsi sebagaimana dimaksud pada ayat (3) diatur dengan Peraturan Pemerintah. (sudah ada Putusan Mahkamah Konstitusi No. 5/ PUU-VIII/2010, bahwa Pasal 31 ayat (4) bertentangan dengan UndangUndang Dasar Negara Republik Indonesia Tahun 1945 dan tidak mempunyai kekuatan hukum mengikat).

Uji materi terhadap Pasal 5 ayat (1) dan ayat (2) serta Pasal 44 huruf b Undang-Undang ITE dan Pasal 26A Undang-Undang Nomor 20 Tahun 2001 tentang Perubahan Undang-Undang Nomor 31 Tahun 1999 tentang Pemberantasan 
Tindak Pidana Korupsi oleh Setya Novanto sebagai pemohon, karena frasa informasi elektronik dan/atau dokumen elektronik dalam pasalpasal tersebut tidak jelas atau mempunyai multi tafsir yang apabila tidak diberi tafsir yang jelas oleh mahkamah akan sangat berpotensi melahirkan situasi ketakutan dalam masyarakat untuk berbuat atau tidak berbuat sesuatu karena adanya kekhawatiran akan direkam/disadap oleh pihak yang tidak berwenang. ${ }^{9}$

Mahkamah Konstitusi dalam Putusan Nomor 20/ PUUXIV/2016, menyatakan bahwa frasa informasi elektronik dan/ atau dokumen elektronik dalam Pasal 5 ayat (1) dan ayat (2) serta Pasal 44 huruf $b$ Undang-Undang ITE bertentangan dengan UndangUndang Dasar Negara Republik Indonesia Tahun 1945 dan tidak mempunyai kekuatan hukum mengikat, sepanjang tidak dimaknai khususnya frasa Informasi elektronik dan/ atau dokumen elektronik sebagai alat bukti dilakukan dalam rangka penegakan hukum atas permintaan kepolisian, kejaksaan dan/atau institusi penegak hukum lainnya yang ditetapkan berdasarkan undang-undang sebagaimana ditentukan dalam Pasal 31 ayat (3) Undang-Undang ITE.

Selanjutnya dalam Putusan Mahkamah Konstitusi Nomor 20/PUU-XIV/2016, juga menyatakan bahwa frasa informasi elektronik dan/ atau dokumen elektronik dalam Pasal 26A Undang-Undang Nomor 20 Tahun 2001 tentang Perubahan UndangUndang Nomor 31 Tahun 1999

${ }^{9}$ Putusan Mahkamah Konstitusi Nomor 20/ PUU$\mathrm{XIV} / 2016$. tentang Pemberantasan Tindak

Pidana Korupsi bertentangan dengan Undang-Undang Dasar Negara Republik Indonesia Tahun 1945 dan tidak mempunyai kekuatan hukum mengikat, sepanjang tidak dimaknai khususnya frasa Informasi elektronik dan/ atau dokumen elektronik sebagai alat bukti dilakukan dalam rangka penegakan hukum atas permintaan kepolisian, kejaksaan dan/atau institusi penegak hukum lainnya yang ditetapkan berdasarkan undangundang sebagaimana ditentukan dalam Pasal 31 ayat (3) UndangUndang ITE.

Berdasarkan Putusan Mahkamah Konstitusi Nomor 20/ PUU-XIV/2016 tersebut, dapat dikatakan bahwa informasi elektronik dan/ atau dokumen elektronik dalam Pasal 5 ayat (1) dan ayat (2) serta Pasal 44 huruf b Undang-Undang ITE dan Pasal 26A Undang-Undang Nomor 20 Tahun 2001 tentang Perubahan Undang-Undang Nomor 31 Tahun 1999 tentang Pemberantasan Tindak Pidana Korupsi, sebagai alat bukti dilakukan dalam rangka penegakan hukum atas permintaan kepolisian, kejaksaan dan/atau institusi penegak hukum lainnya yang ditetapkan berdasarkan undang-undang sebagaimana ditentukan dalam Pasal 31 ayat (3) Undang-Undang ITE. Dengan demikian informasi elektronik dan/ atau dokumen elektronik sebagai alat bukti harus diperoleh sesuai dengan ketentuanPasal 31 ayat (3) Undang-Undang ITE yang menyatakan"Kecuali intersepsi sebagaimana dimaksud pada ayat (1) dan ayat (2), intersepsi yang dilakukan dalam rangka penegakan hukum atas permintaan kepolisian, kejaksaan, dan/atau institusi 
penegak hukum lainnya yang ditetapkan berdasarkan undangundang."

Dengan adanya putusan Mahkamah Konstitusi Nomor 20/ PUUXIV/2016 tersebut, lebih memberi kepastian hukum mengenai tafsir informasi elektronik dan/ atau dokumen elektronik dalam Pasal 5 ayat (1) dan ayat (2) serta Pasal 44 huruf $b$ Undang-Undang ITE dan Pasal 26A Undang-Undang Nomor 20 Tahun 2001 tentang Perubahan Undang-Undang Nomor 31 Tahun 1999 tentang Pemberantasan Tindak Pidana Korupsi. Selain itu tersangka atau terdakwa juga memperoleh keadilan berkaitan dengan informasi elektronik dan/ atau dokumen elektronik sebagai alat bukti dilakukan dalam rangka penegakan hukum atas permintaan kepolisian, kejaksaan dan/atau institusi penegak hukum lainnya yang ditetapkan berdasarkan undang-undang sebagaimana ditentukan dalam Pasal 31 ayat (3) Undang-Undang ITE.

\section{H. Kesimpulan}

1. Pengaturan alat bukti dalam hukum acara pidana di Indonesia sesuai dengan Pasal 184 KUHAP, Pasal 5 ayat (1) dan (2) serta Pasal 44 huruf Undang-Undang ITE, yaitu meliputi keterangan saksi, keterangan ahli, surat, petunjuk, keterangan terdakwa, informasi elektronik dan/atau dokumen elektronik dan/atau hasil cetaknya.

2. Dengan adanya putusan Mahkamah Konstitusi Nomor 20/ PUU-XIV/2016 tersebut, lebih memberi kepastian hukum mengenai tafsir informasi elektronik dan/ atau dokumen elektronik dalam Pasal 5 ayat (1) dan ayat (2) serta Pasal 44 huruf b Undang-
Undang ITE dan Pasal 26A Undang-Undang Nomor 20 Tahun 2001 tentang Perubahan Undang-Undang Nomor 31 Tahun 1999 tentang Pemberantasan Tindak Pidana Korupsi. Selain itu tersangka atau terdakwa juga memperoleh keadilan berkaitan dengan informasi elektronik dan/ atau dokumen elektronik sebagai alat bukti dilakukan dalam rangka penegakan hukum atas permintaan kepolisian, kejaksaan dan/atau institusi penegak hukum lainnya yang ditetapkan berdasarkan undangundang sebagaimana ditentukan dalam Pasal 31 ayat (3) Undang-Undang ITE.

\section{Daftar Pustaka:}

Bakhri, Syaiful, Beban Pembuktian dalam Beberapa Praktek Peradilan, Jakarta: Gramata Publishing, 2012.

Fajar Mukti ND dan Yulianto Achmad, Dualisme Penelitian Hukum Normatif dan Empiris, Yogyakarta: Pustaka Pelajar,2013.

Hamzah, Andi, Hukum Acara Pidana Indonesia, Jakarta: Sinar Grafika, 2017.

Harahap, M. Yahya,Pembahasan Permasalahan dan Penerapan KUHAP : Pemeriksaan Sidang Pengadilan, Banding, Kasasi, dan Peninjauan Kembali , Jakarta: Sinar Grafika, 2009.

Kaelan, Negara Kebangsaan Pancasila, Kultural, Historis, Filosofis, Yuridis dan Aktualisasinya, Yogyakarta: Paradigma, 2013.

Muladi dan Barda Nawawi Arief, Bunga Rampai Hukum Pidana, Bandung: P.T. Alumni, 2010.

Nawawi Arief, Barda, Reformasi Sistem Peradilan Pidana, Semarang: Badan Penerbit Universitas Diponegoro, 2012. 
------------, Bunga rampai Kebijakan Hukum Pidana: Perkembangan Penyusunan Konsep KUHP Baru, Jakarta, Kencana Prenadamedia Group, 2014.

Putra Jaya, Nyoman Serikat, Pembaharuan Hukum Pidana, Semarang : PT. Pustaka Rizki Putra, 2017.

Rahardjo, Satjipto, Ilmu Hukum, Bandung, Citra Aditya Bakti, 2000.

Soekanto, Soerjono dan Sri Mamudji, Penelitian Hukum Normatif (suatu Tinjauan Singkat), Jakarta : Rajawali Press, 2007.

Sudarto, Hukum Pidana I, Semarang: Penerbit Yayasan Sudarto, 2009.

\section{Peraturan :}

Undang-Undang Nomor 8 Tahun 1981 tentang Hukum Acara Pidana.

Undang-Undang Nomor 31 Tahun 1999 tentang Pemberantasan Tindak Pidana Korupsi sebagaimana diubah dengan Undang-Undang Nomor 20 Tahun 2001 tentang Perubahan Undang-Undang Nomor 31 Tahun 1999 tentang Pemberantasan Tindak Pidana Korupsi.

Undang-Undang Nomor 21 Tahun 2007 tentang Pemberantasan Tindak Pidana Perdagangan Orang.
Undang-Undang Nomor 11 Tahun 2008 tentang Informasi dan Transaksi Elektronik sebagaimana diubah dengan Undang-Undang Nomor 19 Tahun 2016 tentang Perubahan Atas Undang Nomor 11 Tahun 2008 tentang Informasi dan Transaksi Elektronik.

Undang-Undang Nomor 8 Tahun 2010 tentang Pencegahan dan Pemberantasan Tindak Pidana Pencucian Uang.

Putusan Mahkamah Konstitusi Nomor 34/PUU-XI/2013.

Putusan Mahkamah Konstitusi Nomor 20/ PUU-XIV/2016.

\section{Website:}

"Soal Penyadapan, Ini Alasan MK Kabulkan Uji Materi Setya (https://m.tempo.co/read/news/201 6/09/07/063802453/soalpenyadapan-ini-alasan-mkkabulkan-uji-materi-setya, diakses 19 Agustus 2017). 